\title{
Pablo Picasso's Mother and Child by the Sea (1902): report on the hyperspectral near-infrared reflectance imaging survey of Picasso's newspaper use
}

\author{
Keiko Imai ${ }^{1}$ [D · John K. Delaney ${ }^{2} \cdot$ Sandra Webster-Cook $^{3} \cdot$ Reyes Jiménez Garnica ${ }^{4}$
}

Received: 4 February 2019 / Accepted: 28 July 2020 / Published online: 4 August 2020

(c) Springer Nature Switzerland AG 2020

\begin{abstract}
Picasso reused the canvas of Mother and Child by the Sea (1902) several times. A hyperspectral near-Infrared (960-1680 nm) reflectance imaging survey of the painting revealed newsprint text from Le Journal of January 1902. Newsprint from Le Journal was identified as well in two other paintings, Jaume Sabartés with Pince-Nez (1901) and Portrait of Mateu Fernández de Soto (1901). Picasso transported these two portraits from Paris to Barcelona along with Mother and Child by the Sea. In all cases, the newsprint letters appear reversed. This presumably was the result of newspaper being applied, for the purpose of transport, to the surface of paintings that were not entirely dry. Inspection of the painting and the infrared hyperspectral images suggest that once this 'ink transfer' occurred it appears that Picasso left the newsprint text in place when he went on to complete the painting. Although Picasso's use of newspaper in his compositions is not unusual, further investigation of the presence of newsprint letters in Blue Period works is of interest. Moreover, the survey's identification of the particular date of the newspaper in question provides important information regarding the timing of Picasso's movement from Paris to Barcelona, and concerning his repainting and completion of each work.
\end{abstract}

Keywords Pablo Picasso · Blue period · Painting · Hyperspectral near-infrared reflectance imaging $\cdot$ Reused canvas · Newspaper

\section{Introduction}

Picasso's Blue Period painting Mother and Child by the Sea (1902, oil on canvas, $81.7 \times 59.8 \mathrm{~cm}$, Pola Museum of Art, Hakone, Z. VI, 478) (Fig. 1) is dedicated to Dr. Josep Fontbona (1876-1940), brother of Picasso's friend and sculptor Emile Fontbona (1879-1938) of Barcelona. The image is modeled after a woman Picasso encountered in 1901 at the Prison of Saint-Lazare in Paris where women would be incarcerated with their infants. Picasso continued painting on the Saint-Lazare prison 'mother and child' theme even after moving from Paris to Barcelona in January 1902 [3, $4]^{1}$

\footnotetext{
1 Pierre Daix relates Picasso's comment concerning these paintings: "Picasso, en lisant la première édition de Picasso 1900-1906, et surtout après la révélation par la radiographie de la Femme au bonnet sous le portrait de Sabartés, m'a expliqué que les toiles bleues que nous avions placées à Barcelone étaient précisément la suite des maternités de Saint-Lazare, bien qu'il n'eût plus travaillé d'après les modèles." Daix P (1977) p. 57, Note 1.
}

Keiko Imai, k-imai@pola-art-foundation.jp; John K. Delaney, J-Delaney@NGA.GOV; Sandra Webster-Cook, Sandra.Webster-Cook@ago.ca; Reyes Jiménez Garnica, rjimenezga@bcn.cat | ${ }^{1}$ Pola Museum of Art, Hakone, Japan. ${ }^{2}$ National Gallery of Art, Washington, USA. ${ }^{3}$ Art Gallery of Ontario, Toronto, Canada. ${ }^{4}$ Museu Picasso, Barcelona, Spain. 


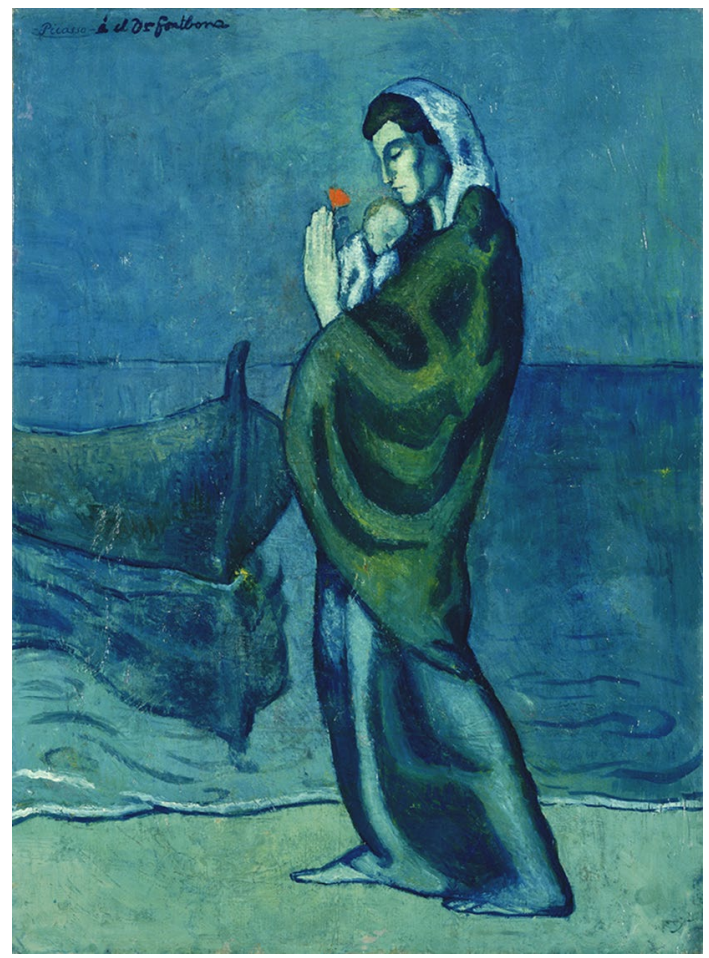

Fig. 1 Pablo Picasso, Mother and Child by the Sea, 1902, oil on canvas, $81.7 \times 59.8 \mathrm{~cm}$, Pola Museum of Art, Hakone $\odot$ Pablo Picasso's Estate. VEGAP. Madrid, 2020. Permission to reproduce courtesy of VEGAP

Mother and Child by the Sea is thought to have been completed in Barcelona in January 1902. It may be the Barcelona coast seen in the background. The Fontbona family let go of the painting in 1957, after which it appeared in auctions and changed hands among different collectors. Tsuneshi Suzuki (1930-2000), owner of the Pola-Orbis Group and an avid collector, acquired the painting in the 1980s. His collection opened to the public in 2002, with the establishment of the Pola Museum of Art.

The condition of Mother and Child by the Sea is as it was at the time of the Pola acquisition, including the presence of a linen backing. Recent inspection shows there are traces of restoration and a surface coat of varnish. The painting surface appears uneven, even to the naked eye, and unrelated texture suggests a composition beneath the surface. Three optical surveys on Mother and Child by the Sea have been done. The first was in 1997 by Ms. Ann Hoenigswald of the National Gallery of Art, Washington DC, who took an X-ray radiograph and infrared photos at the time of the Picasso: The Early Years exhibition at the National Gallery of Art, Washington, DC and the Museum of Fine Arts, Boston.

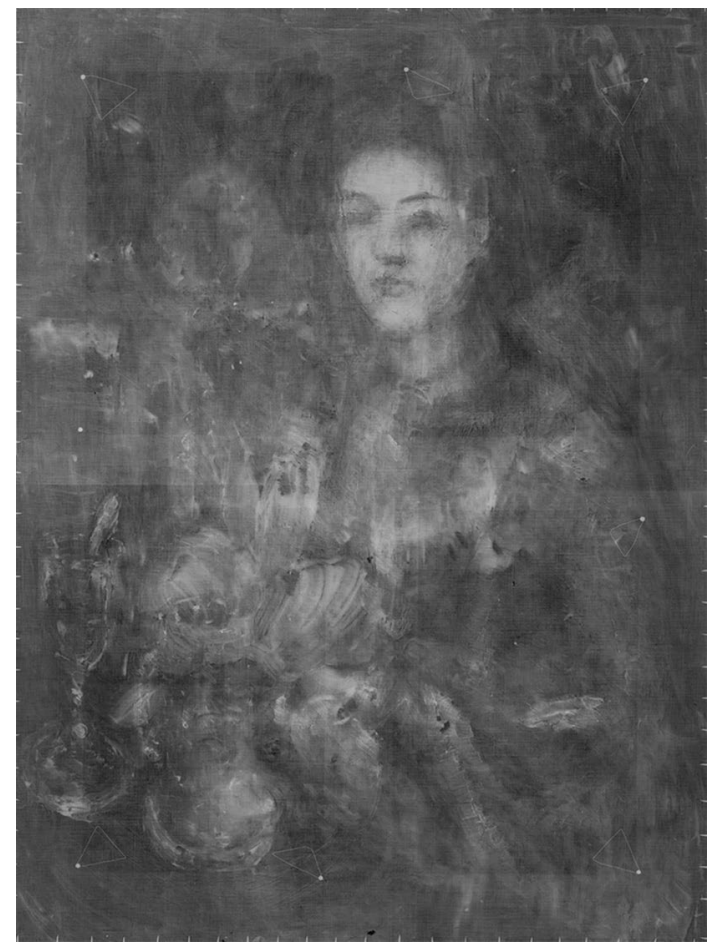

Fig. 2 X-ray radiograph, Mother and Child by the Sea (C) Pola Museum of Art/National Research Institute for Cultural Properties, Tokyo

In 2005, the Pola Museum of Art collected an X-ray radiograph image of Mother and Child by the Sea in cooperation with Tokyo National Research Institute for Cultural Properties. The radiograph revealed a previously hidden female figure [7, 11] (Fig. 2). In addition, the 2005 radiograph revealed an absinthe glass and spoon. These recall Picasso's paintings of women in Paris bars in the fall and winter of 1901. The radiograph images also showed the image of a head of a second female figure likely to be in a lower paint layer, suggesting compositional revision.

In April 2018 near-infrared reflectance imaging spectroscopy (NIR-RIS) was done on Mother and Child by the Sea using a hyperspectral camera system from the National Gallery of Art, Washington, DC, in order to further the understanding of the history of this painting in preparation for the Art Gallery of Ontario (AGO) and The Philips Collection joint exhibition. Sandra WebsterCook and Kenneth Brummel of AGO proposed the survey to the Pola Museum of Art. All participated in the current survey.

Near-infrared reflectance imaging spectroscopy has been shown in prior studies to provide improved 


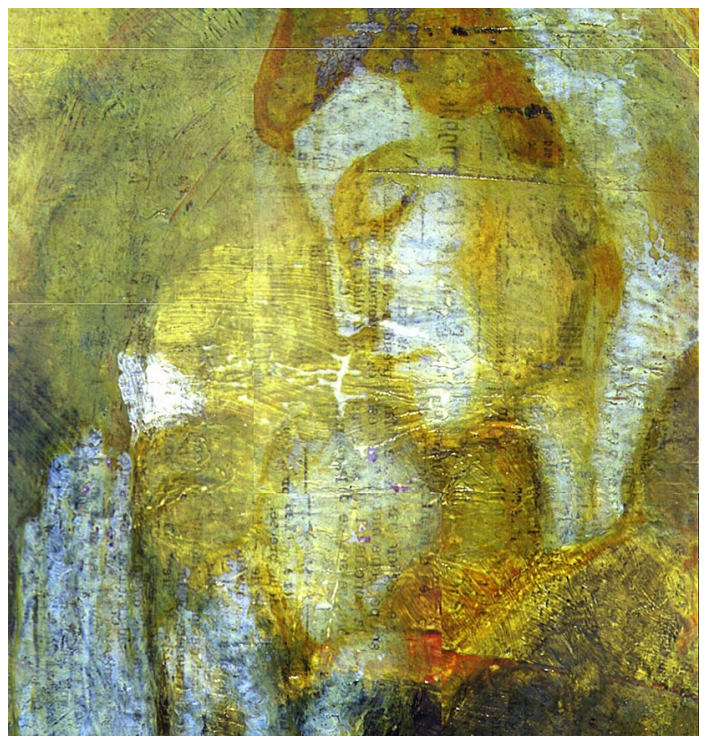

Fig. 3 Detail of Infrared false color image of Mother and Child by the Sea $\odot$ John K. Delaney, National Gallery of Art, Washington, 2018

visualization of earlier painted compositions in Blue Period paintings by Picasso [6]. A large number of hyperspectral near-infrared reflectance image cubes were collected and mosaicked together to create one large image cube from which false color images were created to make the newsprint letters clearer to see. ${ }^{2}$ Near-infrared reflectance imaging spectroscopy often provides complementary information to X-ray radiography since it is sensitive to infrared absorbing pigments not detected by $\mathrm{X}$-ray radiography.

\footnotetext{
${ }^{2}$ Near-infrared reflectance imaging spectroscopy [2] was performed with a high sensitivity customized scanning hyperspectral camera that has been previous described [6]. The camera is optimally sensitive from 967 to $1680 \mathrm{~nm}$ and has a spectral sampling of $3.4 \mathrm{~nm}$. The spatial sampling is $0.17 \mathrm{~mm}$ per pixel at the painting. In brief the camera consists of imaging spectrometer with an internal scan mirror that collects image cubes $(640 \times 640$ spatial pixels by 256 spectral) in $3 \mathrm{~min}$ at an illumination level of $700 \mathrm{~lx}$ at the painting from two incandescent lamps on a rheostat. Some 180 image cubes where collected and registered with a true color image to create the mosaicked image cube using the NGA-GWUHSI-Registration algorithm [5]. The resulting data was analyzed in ENVI (Harris, USA). ENVI was also used to make false color images and principal component (PC) images that were found to improve the visibility of the newspaper text or prior painted compositions. PC imaging processing has been found to aid in recovering lost text in palimpsest as well as improving the visibility of painted over features when applied to multi band images.
}

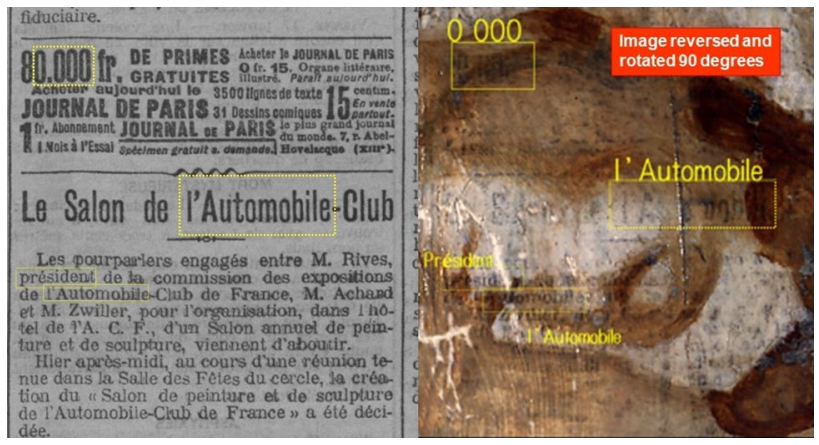

Fig. 4 [Left]: Le Journal, January 18, 1902, page 3, Bibliothèque nationale de France, Source gallica.bnf.fr/BnF, [Right]: Reversed detail of Infrared false color image of Mother and Child by the Sea $\odot$ John K. Delaney, National Gallery of Art, Washington, DC 2018

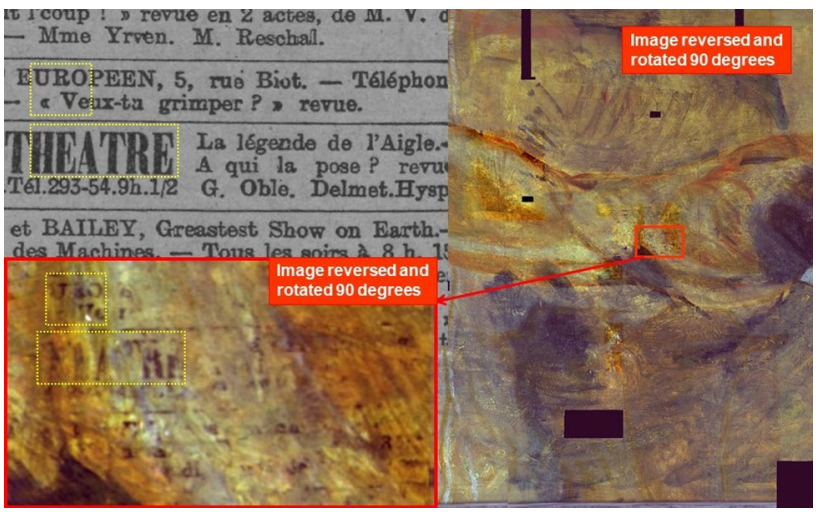

Fig. 5 [Left]: Le Journal, January 18, 1902, page 8, Bibliothèque nationale de France, Source gallica.bnf.fr/BnF, [Right]: Reversed details of Infrared false color image of Mother and Child by the Sea $\odot$ John K. Delaney, National Gallery of Art, Washington, DC 2018

\section{Hyperspectral near-infrared reflectance imaging survey results}

1. The newsprint letters seen on the facial area of Mother and Child by the Sea (Fig. 3) allowed the identification that they were from page 3 of the January 18th, 1902, edition of the French newspaper Le Journal (Fig. 4). ${ }^{3}$ This newsprint letters were not readily detected from visual inspection of the surface of the painting by eye. The infrared images showed aside from the newsprint text in the area of the faces and hand, there are also traces in the lower section of the painting. The newsprint letters seen in the lower section of the painting

\footnotetext{
3 Hyperspectral Imaging clearly showed the words "I'Automobile" and "président." After searching in the "Gallica", the digital library of the Bibliothèque nationale de France $(\mathrm{BnF})$, the archives of Le Journal, known to be familiar to Picasso. It was possible to identify an issue from January 18,1902, which revealed an exact match of the text visible in the hyperspectral images.
} 


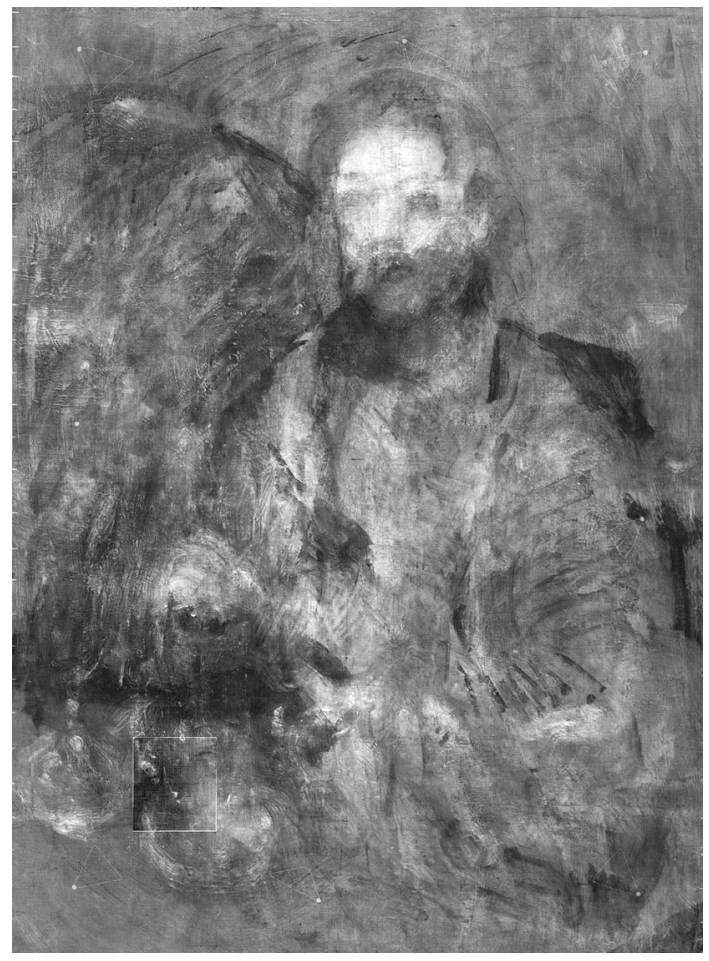

Fig. 6 Composite image of principal component analysis of infrared hyperspectral imaging and X-ray radiograph of Mother and Child by the Sea $\odot$ John K. Delaney, National Gallery of Art, Washington, DC 2018, ( Pola Museum of Art/National Research Institute for Cultural Properties, Tokyo

were identified as being from page 8 of the January 18th edition of Le Journal (Fig. 5).

2. The research allowed a more detailed understanding of Picasso's female images and motifs of his paintings of women in Paris bars (Fig. 6). The Principal Component Analysis (PCA) images support the presence of multiple repaintings.

3. A clear image of the signature "-Picasso-", inscribed upside-down underneath the upper right corner of Mother and Child by the Sea, was confirmed in the under layer of the painting. This suggests that this had been a completed painting previous to the portrait of the woman seated in a bar. It was also discovered that Picasso rotated the canvas 180 degrees before creating the portrait from later in his Paris period.

According to the findings of our hyperspectral nearinfrared reflectance imaging survey, the newsprint is from a January 18, 1902 French newspaper (Fig. 7). This strongly supports the theory that Picasso moved to Barcelona in the latter half of January. Prior to the newsprint discovery, it was thought that Picasso moved to Barcelona in early January, according to Picasso's friend Sabartés [10]. ${ }^{4}$

\footnotetext{
4 Sabartés J (1996) Picasso: Portraits et souvenirs, pp 110-111.
}

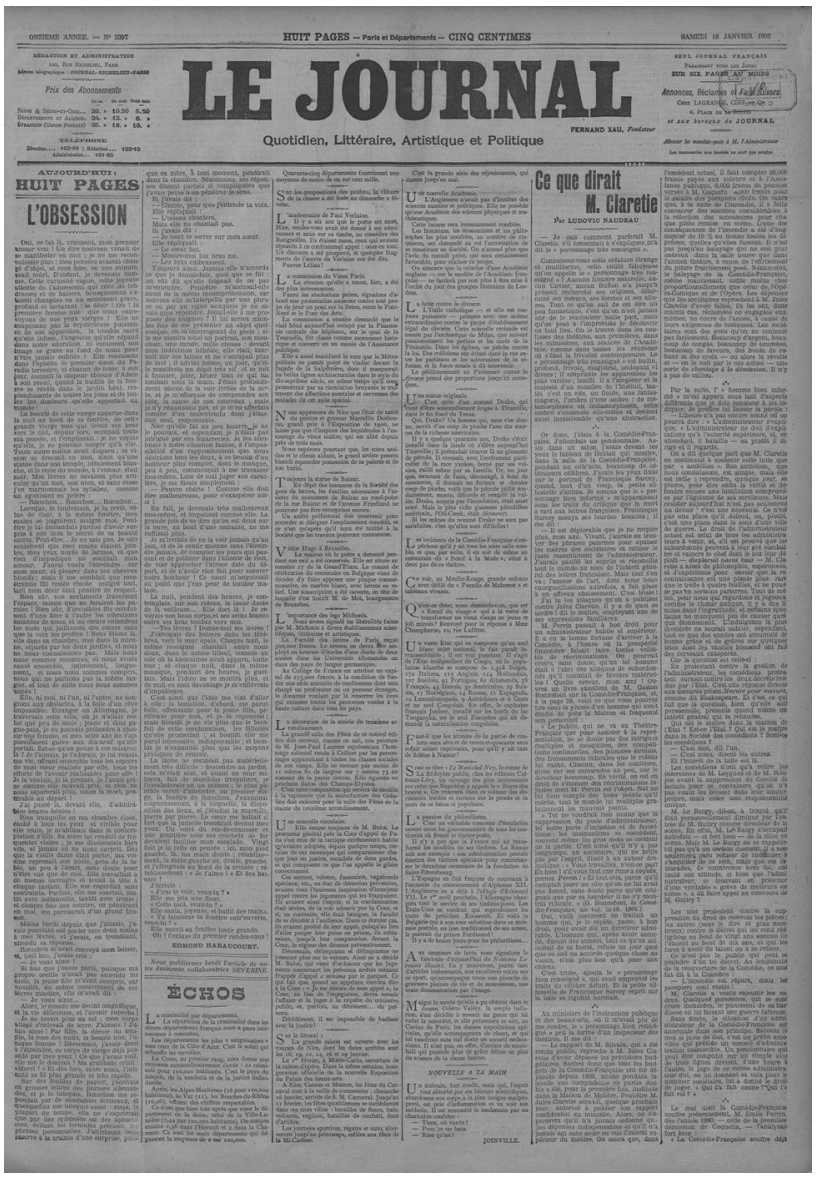

Fig. 7 Le Journal, front page, January 18, 1902, Bibliothèque nationale de France, Source gallica.bnf.fr/BnF

The current research conclusively affirms that Mother and Child by the Sea was transported from Paris to Barcelona by Picasso, no earlier than January 18th.

\section{Identification of newsprint letters}

In summary during the hyperspectral near infrared reflectance image survey, newsprint letters were identified over wide areas of the painting, specifically, throughout the mother and child, the seashore, and in parts of the sky. The newsprint letters appeared over roughly half of the painting, particularly in the central and lower sections. It is also important to note that all newsprint letters found appear in reverse.

We initially assumed newspaper was physically attached to the underlayer painting and represented a part of Picasso's production process. However close inspection, guided by the infrared images and with optical magnification, found that red, yellow, and white colors can 


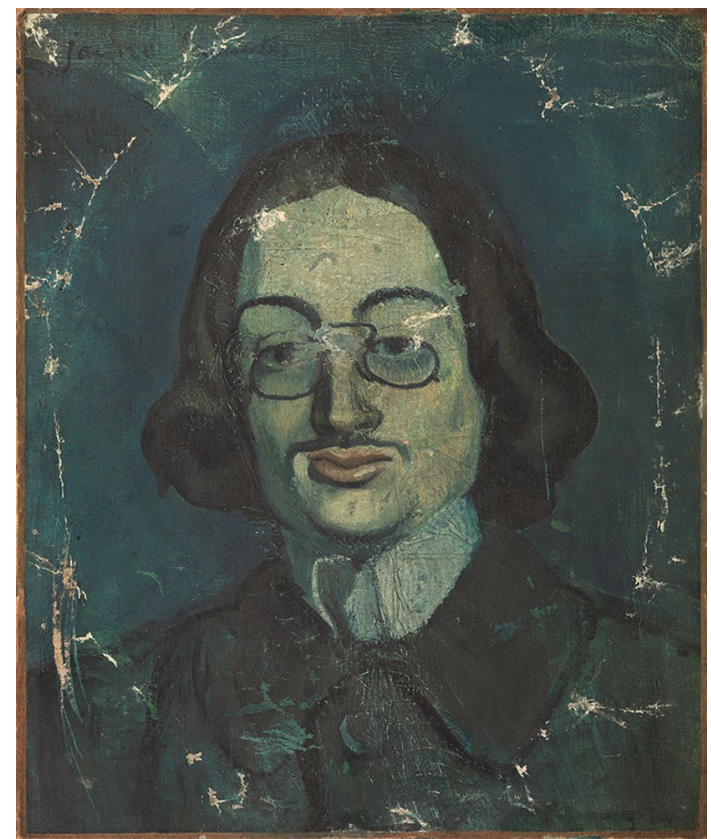

Fig. 8 Pablo Picasso, Jaume Sabartés with Pince-Nez,1901, oil on canvas, $46 \times 38 \mathrm{~cm}$, Museu Picasso, Barcelona (c) Pablo Picasso's Estate. VEGAP. Madrid, 2020. Permission to reproduce courtesy of VEGAP

be seen through surface cracks on the painting, and the reversed letters "sid" of the word "président" could be seen on the Mother's face. Physical evidence of newspaper has not been detected. Interestingly, the reversed newsprint

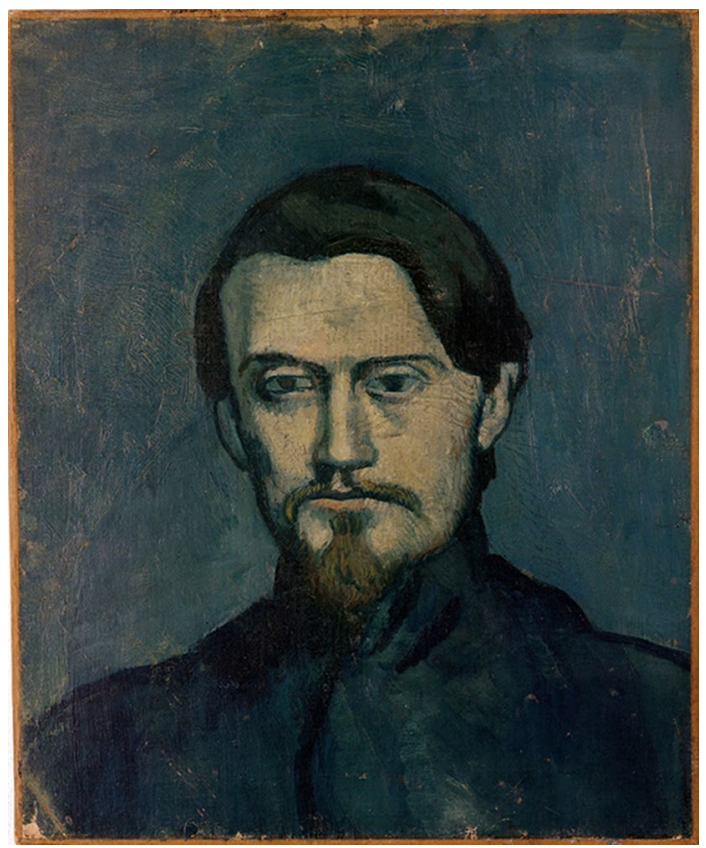

Fig. 9 Pablo Picasso, Portrait of Mateu Fernández de Soto,1901, oil on canvas, $46 \times 38 \mathrm{~cm}$, Private collection $\odot$ B Bidgeman Images, (c) Pablo Picasso's Estate. VEGAP. Madrid, 2020. Permission to reproduce courtesy of VEGAP

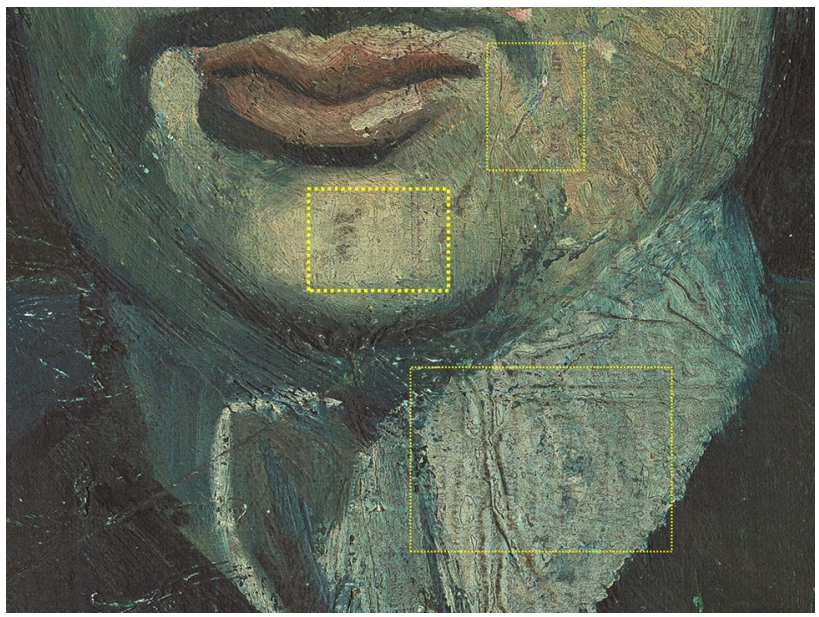

Fig. 10 Detail of Jaume Sabartés with Pince-Nez @ Pablo Picasso's Estate. VEGAP. Madrid, 2020. Permission to reproduce courtesy of VEGAP

letters seemed to be only from one side of the newspaper page.

To further understand these findings an investigation was carried out on two Picasso paintings from the same time period, Jaume Sabartés with Pince-Nez (1901, oil on canvas, $46 \times 38 \mathrm{~cm}$, Museu Picasso, Barcelona, Z. I, 87) (Fig. 8), and Portrait of Mateu Fernández de Soto (1901, oil on canvas, $46 \times 38 \mathrm{~cm}$, Private collection, Z. I, 86) (Fig. 9). The two paintings of Picasso's close friends are roughly the same size and share much in common. They both seem to have been painted in 1901. The canvas of the Mother and Child by the Sea and these two portraits were among the few paintings carried by Picasso from Paris to Barcelona in January 1902.

A prior X-ray radiograph of Jaume Sabartés with PinceNez revealed a portrait of a woman from the Saint-Lazare prison in the layer beneath the surface. High-resolution color imaging of the two paintings revealed as well newsprint letters on the surface of the two portraits. According to Reyes Jiménez who has long studied Jaume Sabartés with Pince-Nez, newsprint letters from Le Journal detected on the surface is from page 2 of January 18th, 1902, the same day as the edition identified in Mother and Child by the Sea (Figs. 10, 11). In both cases, the newsprint appears in reverse and the physical newspaper is not found. ${ }^{5}$

\footnotetext{
5 Delaney, Jiménez, and Imai carried out a survey on Jaume Sabartés with Pince-Nez, including a hyperspectral near-infrared reflectance imaging survey on December 1st 2018 at the Museu Picasso Barcelona. Reversed newsprint lettering was detected and some newsprint ink was observed on the surface of the painting.
} 


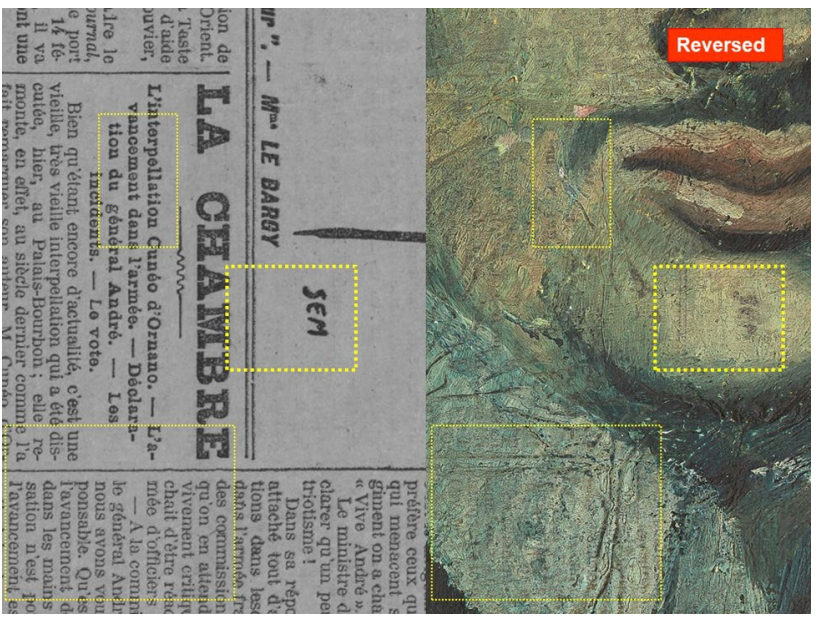

Fig. 11 [Left]: Le Journal, January 18, 1902, page 2, Bibliothèque nationale de France, Source gallica.bnf.fr/BnF, [Right]: Reversed detail of Jaume Sabartés with Pince-Nez $\odot$ Pablo Picasso's Estate. VEGAP. Madrid, 2020. Permission to reproduce courtesy of VEGAP

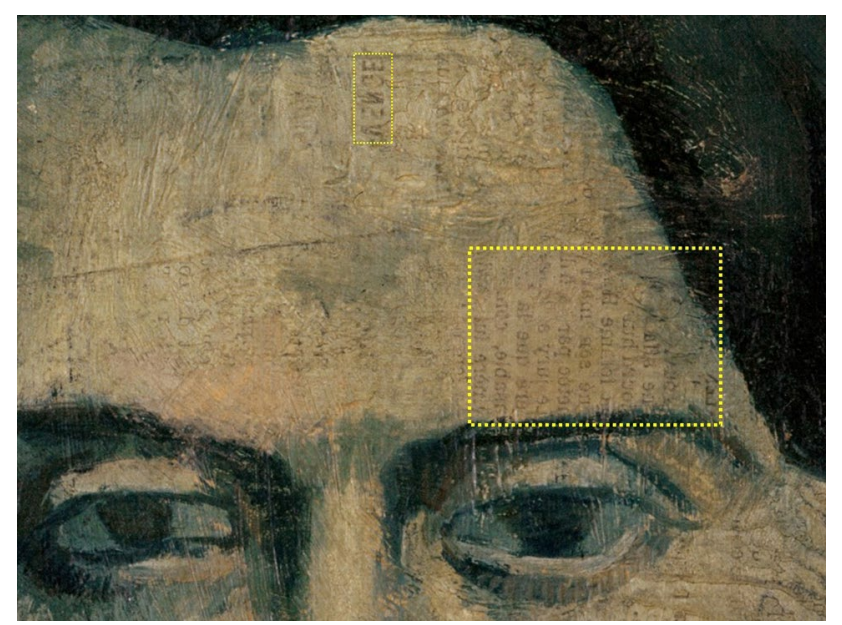

Fig. 12 Detail of Portrait of Mateu Fernández de Soto @ Bridgeman Images, ( Pablo Picasso's Estate. VEGAP. Madrid, 2020. Permission to reproduce courtesy of VEGAP

John Richardson, in Picasso, the Early Years, cites Marilyn McCully mentioning traces of newspaper buried in the Portrait of Mateu Fernández de Soto [9]. ${ }^{6}$ Richardson thought it could be a result of recycling an old canvas and that the portrait could be a repainted one. The highresolution color image of this portrait shows newsprint letters that appear in reverse on the surface of the painting

\footnotetext{
${ }^{6}$ Concerning the Portrait of Mateu de Soto, "McCully has discovered traces of newspaper buried in the underpaint of this portrait-possibly the consequence of recycling an old canvas." See Richardson J (1991) A Life of Picasso, chapter 14, "Painter of Human Misery" note 49 , p. 500.
}

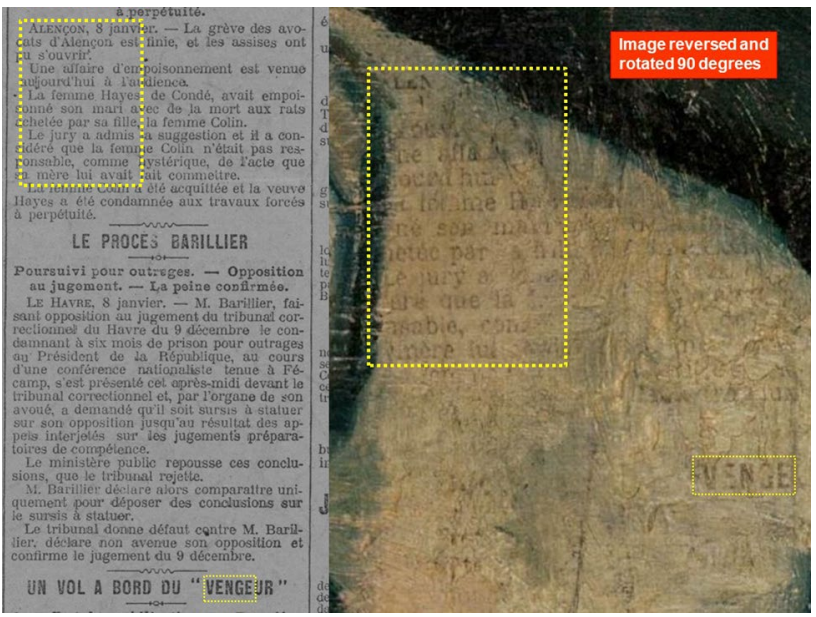

Fig. 13 [Left]: Le Journal, January 9, 1902, page 4, Bibliothèque nationale de France, Source gallica.bnf.fr/BnF, [Right]: Reversed detail of Portrait of Mateu Fernández de Soto @ Bridgeman Images, (c) Pablo Picasso's Estate. VEGAP. Madrid, 2020. Permission to reproduce courtesy of VEGAP

(Fig. 12). The high-resolution color image allowed us to clearly identify the newsprint letters as page 4 of the January 9th, 1902 edition of Le Journal (Fig. 13). ${ }^{7}$

The two portraits of Picasso's friends share many similarities. Wrinkling of the surface paint from pressing newspaper onto the still wet surface of the paintings is thought to be unintentional, rather than deliberate. This time, however, Reyes Jiménez conducted a simulation to see if ink from a newspaper could be transferred to a wet canvas and thus create reverse newsprint letters on a painting using present day newspaper (Fig. 14). Jiménez found that ink of the letters was transferred on the wet paint layer. ${ }^{8}$ This suggests that the newspaper was applied to the paintings before the oil paint was dry, and later removed. Jiménez suggests that the matte surface of Jaume Sabartés with Pince-Nez is possibly a result of the newspaper absorbing oil from the wet painting. The simulation relates also to Jaume Sabartés with Pince-Nez and Portrait of Mateu Fernández de Soto. According to the research, it seems that Picasso completed these two paintings and surprisingly let the newsprint ink and wrinkled newspaper texture remain.

\footnotetext{
7 Newsprint letters observed on the Portrait of Mateu de Soto were clearly matched with the issue of the January 9th, 1902 edition of Le Journal in two sections (Fig. 13). However, the space between the matched two sections is much closer together on the painting than on the original newsprint. Therefore, the newspaper could have been torn and wrinkled before being applied on the painting.

8 Jiménez conducted the simulation of the transfer of the newsprint letters in November 2018 and suggested that Picasso most likely applied the newspaper to the paint when it was still wet. The simulation was done with oil on canvas diluted with walnut oil.
}

\section{SN Applied Sciences}




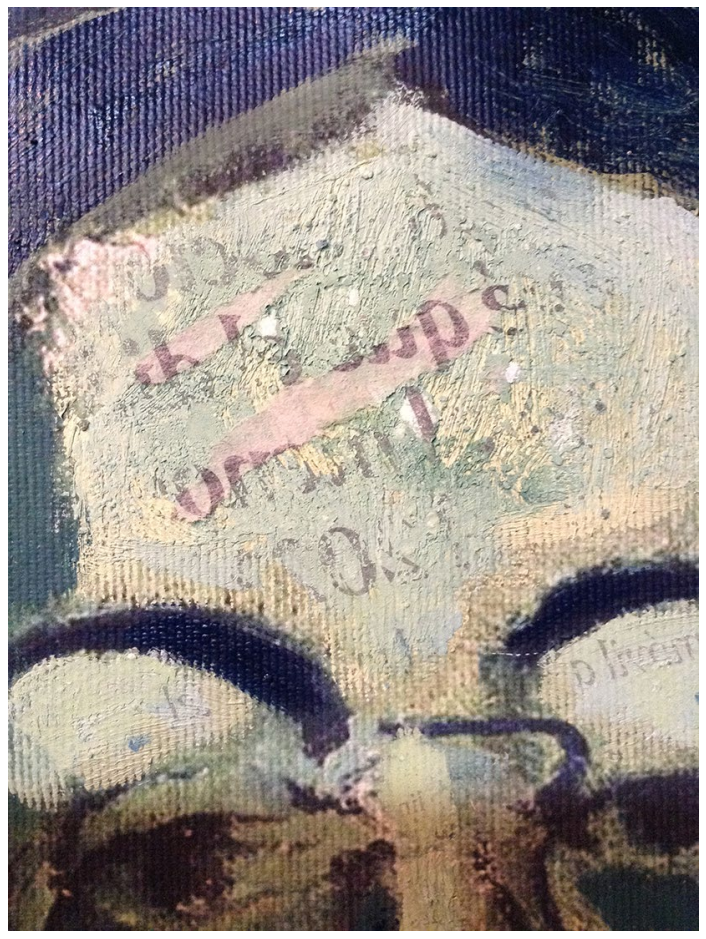

Fig. 14 Simulation of the transfer of newspaper letters on to a painted copy of Jaume Sabartés with Pince-Nez by Reyes Jiménez Garnica, oil on canvas, 2018

Picasso once tried to give Jaume Sabartés with Pince-Nez to Sabartés' family but finally he decided kept it for himself. He also kept Portrait of Mateu Fernández de Soto for himself for the rest of his life. ${ }^{9}$

The canvas of Mother and Child by the Sea is 2.8 times larger than the two portrait paintings. Some of the texture of the painted surface might be due to application of the newspaper when the paint was not quite dry. There are ripples and compression cracks on the painted surface, particularly at the position of the child's head and the mother's chin which suggest rolling with the paint side in, but the cracks do not extend across the painting. The upper paint layers appear to be not well adhered to the underlayer.

The irregular condition of the newsprint letters in Mother and Child by the Sea and Portrait of Mateu Fernández de Soto suggests that the newspaper applied to Portrait of Mateu Fernández de Soto was creased or wrinkled and

\footnotetext{
9 Picasso brought Jaume Sabartés with Pince-Nez to Barcelona to present it to Sabartés' family but finally he kept it for himself until gifting it to Museu Picasso Barcelona in 1968 (see Sabartés J (1996) Picasso: Portraits et souvenirs, pp 111-112 and Richardson J (1991) A Life of Picasso, p. 233). Portrait of Mateu Fernández de Soto was one of only a few Blue Period paintings that Picasso kept in his private collection.
}

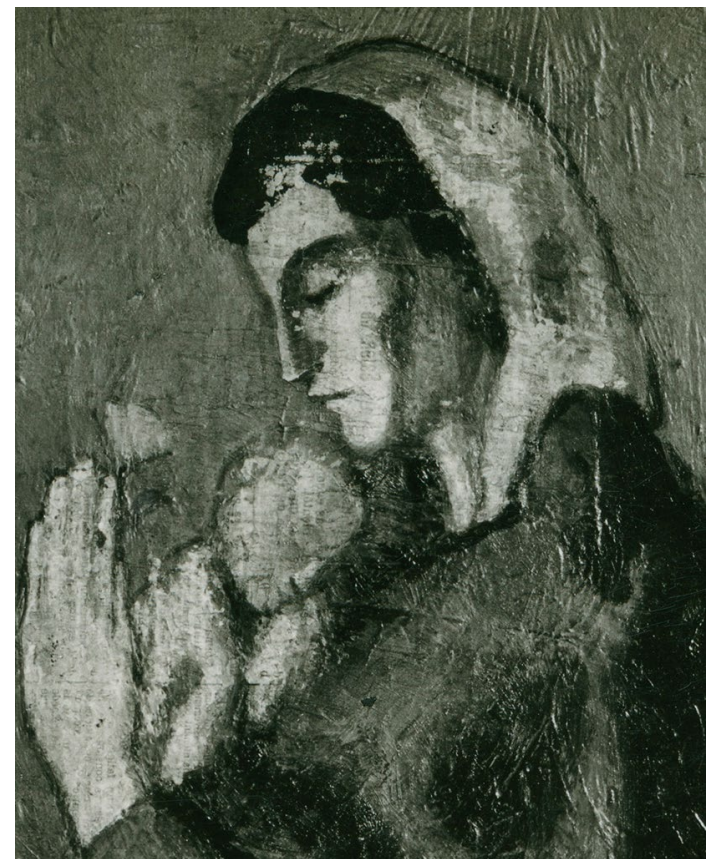

Fig. 15 Mother and Child by the Sea, detail of photo by Francesc Serra i Dimas, n.d., Courtesy of Mr. Francesc Fontbona (c) Pablo Picasso's Estate. VEGAP. Madrid, 2020. Permission to reproduce courtesy of VEGAP

that more than two sheets of the newspaper were applied to Mother and Child by the Sea. Le Journal newspaper consists of two sheets and each sheet has been folded in half to create a folio. Each folio has two leaves that make up the pages of the newspaper. One sheet, or folio, from the January 18 edition of le Journal was cut down the fold to separate the leaves, the leaf labeled as page 8 was applied to the lower section of Mother and Child by the Sea, and the other leaf, labeled as page 2 was placed on the surface of Jaume Sabartés with Pince-Nez. The canvas of Mother and Child by the Sea was transported from Paris to Barcelona along with at least these other two paintings. We can assume that the newspaper was applied to the still wet paintings to facilitate transport. We intend to further investigate each of the works in consideration of these findings.

\section{La Flor del mal and newsprint letters}

Because the transferred newsprint lettering is not clearly exposed on the surface of Mother and Child by the Sea, it was not clear which paint layer contained portions of actual newsprint letters, unlike the other two paintings. However, in November 2018, following the results of the hyperspectral Near-infrared reflectance imaging survey, historian Francesc Fontbona, successor of the Fontbona family that long held the painting, related that 
the newsprint letters had been clearly visible on the surface of the painting when he was a child. He also related that the family often talked about the fact that Picasso gave this painting the title La Flor del mal. He provided a monochrome photograph taken by Francesc Serra i Dimas (1877-1967) (Fig. 15), and a color photograph from the latter half of the 1950s by José Compte Argimon (1910-1987). The photos confirm that most of the newsprint detected by hyperspectral near-infrared reflectance imaging was once more visible on the surface of the painting than now. In other words, the restoration done to the painting after it left the Fontbona family seems to have reduced the visual appearance of the newsprint lettering that still can be detected by hyperspectral near-infrared reflectance imaging within the layers of the painting. One possible explanation is that some of the newspaper ink could have been removed in the cleaning of the painting since the solvents typically used can solubilize ink.

We can therefore propose a hypothesis for the paint layers of Mother and Child by the Sea according to the scientific results and the testimony and photographic materials provided by Mr. Fontbona as follows:

Bottom layer: The painting was completed and signed "-Picasso-." It is assumed to have been done in Paris. Picasso started to use the "-Picasso-" signature after January 1901, when he was in Madrid. This signature was used for the works Picasso submitted to the Vollard Gallery in Paris. The Vollard exhibition (June 24-July 14, 1901) was a success with nearly half of the 64 works sold. Picasso picked up some of the unsold paintings and reused the canvases [8]. Picasso scholars have been trying to identify what works Picasso exhibited in this Vollard show. We need also to verify whether or not the bottom layer painting of Mother and Child by the Sea was included in this exhibition.

Middle layers: These were produced in Paris. Top and bottom were reversed and the new painting, including what seems to be a female figure, a table and a drink, was made. It is also possible that parts of this composition were repeatedly redone until the beginning of Picasso's Blue Period.

Surface layer: Prior to the newsprint discovery, it was thought that Picasso painted Mother and Child by the Sea in Barcelona. The current research affirms that Mother and Child by the Sea was painted between the end of 1901 and January 1902 in Paris. Newspaper pages are affixed to the still wet canvas in Paris after January 18, 1902; the canvas was likely rolled and the newsprint ink remained after the newspaper was peeled off. In Barcelona, the painting may have been inscribed with Picasso's dedication to Dr. Josep Fontbona.

It is necessary to further investigate the surface layer in more detail. Due to restoration done after 1957, very little of the newsprint letters are visible. It is assumed that all the layers of Mother and Child by the Sea were produced in a period of over half a year beginning prior to Picasso's Blue Period in Paris until the beginning of his Blue Period in Barcelona.

\section{Conclusion}

All three works under discussion remained for decades with Picasso's friend's family, or in his own possession. $X$-ray radiographs of Mother and Child by the Sea and Jaume Sabartés with Pince-Nez reveal compositional changes and a separate painting in the layer below the surface. The specific date of the Le Journal newsprint offers concrete evidence of when the three paintings were painted over or completed. It is also apparent that the three paintings for friends have a special connection.

Picasso's many associations with newspaper are well known [1]. From 1912, Picasso often used Le Journal, attaching it to paper, paperboard or canvases for his Cubism Period collages. In 1911, Picasso and Georges Braque had already started including painted letters in their cubist paintings. The current research uncovers the until now unknown role of newspaper linking Picasso's Mother and Child by the Sea and the two other paintings under study. Picasso is likely to have completed the painting, preserving the accidental newspaper lettering. This research suggests the possibility of discovering reverse newsprint letters in other Picasso paintings. The discovery of newsprint resulting from affixing newspaper to oil paint surfaces reveals an important aspect of Picasso's production process and artistic expression.

Acknowledgements We would like to acknowledge and thank Francesc Fontbona, Laurent Le Bon, president of Musée National Picasso - Paris, Emmanuel Guigon, director of Museu Picasso, Barcelona, Kenneth Brummel of Art Gallery of Ontario, Masahide Inuzuka of the National Research Institute for Cultural Properties, Tokyo, and Claire Guerin. We are also grateful to Shunsuke Kijima, Hiroyuki Uchiro, and Yoh Shoji of the Pola Museum of Art. We also thank the National Gallery of Art, Washington, DC for their support of this project. Sponsorship from the Museu Picasso, Barcelona, to cover permission fees for the reproduction of works by Picasso is gratefully acknowledged.

\section{Compliance with ethical standards}

Conflict of interest The authors declare that they have no conflict of interest.

\section{References}

1. Baldassari A (2003) Picasso, Papiers Journaux (Exp. Cat,) Musée Picasso, Paris

2. Cucci C, Delaney JK, Picollo M (2016) Reflectance hyperspectral imaging for investigation of works of art: old master paintings and illuminated manuscripts. Acc Chem Res 49(10):2070-2079 
3. Daix P, Boudaille G, Rosselet J (1966) Picasso 1900-1906. Catalogue raisonné de l'œuvre peint, Ides et Calendes, Neuchâtel

4. Daix P (1977) La vie de peintre de Pablo Picasso. Seuil, Paris

5. Damon MC, Delaney JK, Loew MH (2015) Automatic registration and mosaicking of technical images of old master paintings. Appl Phys A 119(4):1567-1575

6. Delaney JK, Thoury M, Zeibel JG, Ricciardi P, Morales KM, Dooley KA (2016) Visible and infrared imaging spectroscopy of paintings and improved reflectography. Herit Sci 4(1):1-10

7. Imai K (2006) Blue period: Barcelona-Paris. In: Exp. Cat., Picasso Five Themes. Pola Museum of Art, Hakone, pp 34-37 (in Japanese)

8. McCully M, Raeburn M (2018) Euvres exposées à la galerie Vollard, 1901. In: Exp. Cat., Picasso bleu et rose. Musée national PicassoParis, Hazan, pp 391-393
9. Richardson J (1991) A Life of Picasso. 1881-1906. Volume 1. Random House, New York

10. Sabartés J (1946/1996) Picasso: Portraits et souvenirs. Louis Carré \& Maximilien Vox / l'école des lettres, Paris

11. Uchiro H (2006) Hidden images of Mother and Child by the Sea. In: Exp. Cat., Picasso Five Themes. Pola Museum of Art, Hakone, pp 136-140 (in Japanese)

Publisher's Note Springer Nature remains neutral with regard to jurisdictional claims in published maps and institutional affiliations. 